\title{
Characterization of Lipophilic Nutraceutical Compounds in Seeds and Leaves of Perilla frutescens
}

\author{
Seungduk Um ${ }^{1,2,3 \dagger}$, Shiva Ram Bhandari ${ }^{4,5 \dagger}$, Nam-Hoon Kim ${ }^{1,2,3}$, Tae-Jin Yang ${ }^{1,2,3}$, \\ Ju Kyoung Lee ${ }^{6,7}$, and Young-Sang Lee ${ }^{4 *}$ \\ ${ }^{1}$ Department of Plant Science, Seoul National University, Seoul 151-921, Korea \\ ${ }^{2}$ Plant Genomics and Breeding Institute, Seoul National University, Seoul 151-921, Korea \\ ${ }^{3}$ Research Institute for Agriculture and Life Sciences, Seoul National University, Seoul 151-921, Korea \\ ${ }^{4}$ Department of Medical Biotechnology, Soonchunhyang University, Asan 336-745, Korea \\ ${ }^{5}$ Department of Horticultural Crop Research, National Institute of Horticultural \& Herbal Science, Rural Development \\ Administration, Suwon 440-706, Korea \\ ${ }^{6}$ Department of Applied Plant Sciences, Kangwon National University, Chuncheon 200-701, Korea \\ ${ }^{7}$ College of Agriculture and Life Sciences, Kangwon National University, Chuncheon 200-701, Korea
}

\begin{abstract}
Perilla frutescens, which comprises var. frutescens and var. crispa, has been cultivated traditionally in Asian countries as an edible oil, leaf vegetable, and medicinal crop. To evaluate the lipophilic phytonutrient properties of $P$. frutescens, we selected 54 Perilla accessions [19 landraces of var. frutescens (FL), 22 weedy type var. frutescens $(\mathrm{FW}), 9$ weedy type var. crispa (CW), 2 cultivars of var. frutescens widely cultivated for seed oil (FCS), and 2 cultivars of var. frutescens cultivated as a leaf vegetable (FCL)] and analyzed their seeds and leaves for vitamin E, squalene, and phytosterols. Among the four vitamin E isomers analyzed, $\gamma$-tocopherol was the major form of vitamin $\mathrm{E}$ in seeds, whereas $\alpha$-tocopherol was the major form in leaves of all types of $P$. frutescens. The highest total vitamin E content in seeds was present in FL $\left(170.0 \mathrm{mg} \cdot \mathrm{kg}^{-1}\right)$, whereas that in leaves was highest in FCL $\left(358.1 \mathrm{mg} \cdot \mathrm{kg}^{-1}\right)$. The highest levels of squalene in seeds and leaves were in FL $\left(65.5 \mathrm{mg} \cdot \mathrm{kg}^{-1}\right)$ and CW $\left(719.3 \mathrm{mg} \cdot \mathrm{kg}^{-1}\right)$, respectively. Among the three phytosterols, $\beta$ -sitosterol occurred in the highest amount in both leaves and seeds of all of the crop types. Phytonutrient contents were comparatively higher in leaves than in seeds of all crop types. All of these results suggest that the consumption of leaves and seeds of Perilla crops could be beneficial to human health, as Perilla possesses considerable amounts of various lipophilic compounds.
\end{abstract}

Additional key words: Perilla var. crispa, phytosterol, squalene, vitamin E

\section{Introduction}

Perilla frutescens (L.) Britt. (Labiatae) is a self-fertilizing annual plant that is widely cultivated and distributed in the Himalayan hills, Southeast Asia, and East Asia (Makino, 1961; Nitta, 2001). Recently, it has been also grown in various other countries, including the United States, European nations, and Russia (Nitta and Ohnishi, 1999; Nitta et al., 2003). The species includes two cultivated varieties of Perilla that are characterized on the basis of morphology and use. $P$. frutescens var. frutescens is an oil crop, which is known as ren in Chinese, deulkkae in Korean, and egoma in Japanese, whereas $P$. frutescens var. crispa is a Chinese medicinal or vegetable crop called zisu in Chinese, cha-jo-ki in Korean, and shiso in Japanese (Lee et al., 2002). In addition to those two cultivated types of Perilla, weedy plants of both var. frutescens and var. crispa (Lee and Ohnishi, 2001; Nitta and Ohnishi, 1999) are commonly found in habitats such as roadsides, wastelands, abandoned fields, and marginal lands around farm fields in East Asia. The two cultivated types of

\footnotetext{
*Corresponding author: mariolee@sch.ac.kr

${ }^{\dagger}$ These authors contributed equally to this research work.

※ Received 13 September 2012; Revised 27 November 2012; Accepted 29 November 2012. This work was supported in part by the Soonchunhyang University Research Fund (20110694: Reveleris iES Flash Chromatography).
} 
Perilla are distinguished by several morphological features. $P$. frutescens var. frutescens is tall and has large seeds (>2 mm), which are either soft or hard, green leaves and stems, unwrinkled leaves, and a fragrance specific to var. frutescens. In contrast, $P$. frutescens var. crispa is short and has small seeds $(<2 \mathrm{~mm})$, which are hard, either red or green leaves and stems, either wrinkly or non-wrinkly leaves, and a fragrance specific to var. crispa (Lee and Ohnishi, 2001). The plant is occasionally found in a relict form in Korea (Lee and Ohnishi, 2001). P. frutescens var. frutescens is widely cultivated and used in Korea (Lee et al., 2002; Nitta, 2001; Nitta et al., 2003) and believed to have originated in southern China, where a wild type of this plant is widely distributed (Lee and Ohnishi, 2003; Makino, 1960; Nitta et al., 2003). In Korea, var. frutescens has been one of the most important oil crops since ancient times. Var. frutescens has been a vegetable crop, and its seed oil has been used as both edible and industrial oil, including for lamp oil, waterproofing umbrella paper and other rain gear, and as a lacquer for wooden furniture, wooden vessels, and other household items (Choi, 1984). The seeds of var. frutescens have also been used as a folk medicine for inveterate gastritis and cough and as a restorative (Choi, 1984). Recently, considerable attention has been given to the anti-inflammatory, anti-allergic, and anti-tumor promoting substances contained in beefsteak plants (Makino et al., 2003; Ueda et al., 2002). With the increase of meat consumption and development of various methods for cooking the fresh leaves, var. frutescens is used not only as a seed oil crop but also as a leafy vegetable crop and has become one of the most important crops in Korea.

Vitamin E, phytosterols, and squalene are the chief phytonutrients found in the unsaponifiable lipid fraction of crop seeds. Vitamin E, which consists of the four isomers $\alpha$-, $\beta$-, $\gamma$-, and $\delta$ - tocopherol, is a well-known natural antioxidant. By inhibiting membrane lipid peroxidation and scavenging reactive oxygen species (Kruk et al., 2005; Munne-Bosch and Alegre, 2002; Trebst et al., 2002), vitamin E is believed to reduce the risk of cardiovascular diseases and certain types of cancers (Burton, 1994; Burton and Traber, 1990). Phytosterols, primarily $\beta$-sitosterol, campesterol, and stigmasterol, are integral components of plant cell membranes and are found abundantly in vegetable oils, nuts, seeds, and grains (Weihrauch and Gardner, 1978). Phytosterols are mainly known for lowering serum cholesterol (Marangoni and Poli, 2010) and preventing the development of colon cancer (Awad and Fink, 2000) and for their atherosclerotic (Moghadasian et al., 1999), anti-inflammatory (Bouic, 2001), and anti-oxidative effects (van Rensburg et al., 2000). Squalene, a hydrocarbon, is a key intermediate in cholesterol biosynthesis (Moreda et al., 2001) and is abundant in shark liver oil (Squalus spp.) and olive oil. It possesses antitumor, anti-proliferative, and serum-cholesterollowering effects (Khor and Chieng, 1997), along with chemopreventive activity against colon carcinogenesis (Rao et al., 1998).

In this study, we collected various germplasms of Perilla crops and weedy types from different places in Korea and evaluated vitamin E isomers, squalene, and phytosterols in seeds and leaves to develop a highly nutritive variety.

\section{Materials and Methods}

\section{Plant Materials}

The materials used in this study consisted of 54 Perilla accessions, including 19 landrace accessions of var. frutescens (FL), 22 accessions of weedy type var. frutescens (FW), 9 accessions of weedy type var. crispa $(\mathrm{CW})$, and 4 cultivars of var. frutescens, of which 2 were leafy vegetable crops (FCL) and 2 were seed oil crops (FCS). The 54 accessions of cultivated and weedy Perilla types (Table 1) were collected in Korea during October-November 2007 and 2008. We visited more than 30 villages and interviewed numerous farmers about the cultivation and utilization of Perilla crops. We also searched for natural distributions of weedy types of Perilla in farm fields, roadsides, wastelands, abandoned fields, and areas around farmhouses. The collected Perilla samples were classified into cultivated or weedy types based on morphological characters and cultivation conditions (cultivated or not). Four widely cultivated cultivars of var. frutescens developed by the National Institute of Crop Science, Rural Development Administration of Korea, were used as references. To propagate the seeds of the 54 accessions of cultivated and weedy Perilla types, five individuals of each accession were grown in a field at the Faculty of Agriculture, Kangwon National University, Chuncheon, Gangwon Province. For analysis in this study, $10 \mathrm{~g}$ of seeds harvested in 2007 from each accession was used. To analyze the leaf constituents and correlate these with their quantities in seeds, the same 
Table 1. Seeds of Perilla frutescens used in this study.

\begin{tabular}{|c|c|}
\hline Crop types & Accession number \\
\hline $\begin{array}{l}\text { var. frutescens weedy } \\
\text { (FW) }\end{array}$ & $\begin{array}{l}\text { P07-2, P07-5, P07-10, P07-13, P07-15, P07-18, P07-19, P07-20, P07-27, P07-48, } \\
\text { P07-57, P07-58, P07-74, P07-83, P07-87, P07-112, P07-114, P07-115, P07-128, } \\
\text { P07-131, P07-133, P07-160 }\end{array}$ \\
\hline $\begin{array}{l}\text { var. frutescens landrace } \\
\text { (FL) }\end{array}$ & $\begin{array}{l}\text { P07-7, P07-16, PO7-37, P07-39, P07-40, P07-45, P07-49, P07-59, P07-81, P07-122, } \\
\text { P07-126, P07-129, P07-134, P07-135, P07-137, P07-142, P07-147, P07-153, P07-162 }\end{array}$ \\
\hline $\begin{array}{l}\text { var. crispa weedy } \\
(\mathrm{CW})\end{array}$ & P07-17, P07-22, P07-24, P07-138, P07-143, P07-144, P07-145, P07-155, P07-156 \\
\hline $\begin{array}{l}\text { var. frutescens cultivated for seeds } \\
\text { (FCS) }\end{array}$ & 2 cultivars for seed purpose (cv. Perilla Youngho and cv. Perilla Anyu) \\
\hline $\begin{array}{l}\text { var. frutescens cultivated for leaves } \\
\text { (FCL) }\end{array}$ & 2 cultivars for leaf purpose (cv. Perilla Namcheon and cv. Perilla Dongle-1-ho) \\
\hline
\end{tabular}

accessions were planted by direct seeding in June 2008 on the agricultural research farm of Seoul National University, Suwon, Korea. In September, $40 \mathrm{~g}$ of healthy leaves was harvested from 35 well-grown accessions and lyophilized using a freeze-dryer (IlShin BioBase, Korea). The seeds and leaves were then ground into fine powder and stored at $-20^{\circ} \mathrm{C}$ for further analysis.

Sample Preparation for Analysis of Tocopherols, Phytosterols, and Squalene

Samples for the analysis of tocopherols, phytosterols, and squalene were prepared according to Bhandari et al. (2012) with some modifications. Dry powdered Perilla seeds and leaves $(1.0 \mathrm{~g})$ were placed in a $50 \mathrm{~mL}$ Falcon tube and extracted with $15 \mathrm{~mL}$ ethanol using $100 \mathrm{mg}$ ascorbic acid as an antioxidant. The mixture was shaken in a hot-water bath at $80^{\circ} \mathrm{C}$ for $10 \mathrm{~min}$. Then, for saponification, $300 \mu \mathrm{L} 44 \%$ potassium hydroxide was added, and the mixture was shaken for $18 \mathrm{~min}$ under the same conditions. After saponification, each tube was cooled in ice, and $10 \mathrm{~mL}$ of $\mathrm{n}$-hexane and $10 \mathrm{~mL}$ of distilled water were added and mixed, and the mixture was centrifuged at $1900 \times g$ for $10 \mathrm{~min}$. The upper hexane layer was then collected, and $10 \mathrm{~mL} n$-hexane was added to the remaining solution. This process was repeated three times, with the collected hexane solutions pooled and then washed three times with $10 \mathrm{~mL}$ distilled water. The solutions were passed through $\mathrm{Na}_{2} \mathrm{SO}_{4}$ anhydrous to remove water, concentrated in a rotary evaporator, and redissolved in $1 \mathrm{~mL}$ isooctane.

\section{Analysis of Tocopherols, Squalene, and Phytosterols}

Four vitamin $\mathrm{E}$ isomers ( $\alpha-, \beta-, \gamma-$, and $\delta$ - tocopherols), squalene, and three phytosterols (campesterol, stigmasterol, and $\beta$-sitosterol) were quantified using a gas chromatograph (Varian 3800; Varian Inc., Palo Alto, CA, USA) according to Bhandari et al. (2012) The analysis was performed using a CP-SIL 8CB capillary column $(25.0 \mathrm{~m} \times 250 \mu \mathrm{m} \times 0.40 \mu \mathrm{m}$ nominal ) at a constant flow rate $\left(1.0 \mathrm{~mL} \cdot \mathrm{min}^{-1}\right)$ of helium as a carrier gas. The injection volume was $1 \mu \mathrm{L}$, and the split ratio was 1:20. The temperature for the injector and flame ionization detector was set at $290^{\circ} \mathrm{C}$. The column oven temperature was initially set at $220^{\circ} \mathrm{C}$ for $2 \mathrm{~min}$, then raised to $290^{\circ} \mathrm{C}$ at a rate of $5^{\circ} \mathrm{C} \cdot \mathrm{min}^{-1}$ and held for $14 \mathrm{~min}$, after which the temperature was raised to $310^{\circ} \mathrm{C}$. All of the vitamin $\mathrm{E}$, squalene, and phytosterols peaks were identified by comparison to the retention time of authentic standard peaks.

\section{Standard Solution Preparation}

External standard solutions of the four vitamin $\mathrm{E}$ isomers were prepared by dissolving the authentic standards separately in isooctane to prepare 1,000 ppm stock solutions. Later, they were mixed and diluted to proper concentrations. Similarly, standard stock solutions of squalene and the phytosterols were separately dissolved in isooctane and chloroform, respectively, and further diluted to the desired concentrations.

\section{Chemicals and Reagents}

Vitamin E standards ( $\alpha-, \beta-, \gamma-$, and $\delta$-tocopherol) were purchased from Merck (Darmstadt, Germany). Squalene, stigmasterol, $\beta$-sitosterol, and campesterol were obtained from Sigma-Aldrich (St. Louis, MO, USA). Ascorbic acid, chloroform, and anhydrous sodium sulfate were acquired from Samchun (Seoul, Korea), potassium hydroxide was 
purchased from Daejung (Seoul, Korea), and ethanol was obtained from Duksan Chemicals (Seoul, Korea). Hexane (HPLC grade) and isooctane (2,2,4-trimethyl pentane; HPLC grade) were purchased from J.T. Baker (Phillipsburg, NJ, USA).

\section{Statistical Analysis}

For quantitative studies, at least three independent sample extraction replications were conducted. Descriptive statistical analyses were performed using SPSS (ver. 18; SPSS, Inc., Chicago, IL, USA) at a significance level of $P=0.05$.

\section{Results and Discussions}

\section{Vitamin E Content}

Vitamin E analysis of all types of $P$. frutescens evaluated in this study showed that only tocopherols were present in both seeds and leaves (Table 2). Seeds of all types of P. frutescens exhibited the highest $\gamma$-tocopherol content among the four tocopherol isomers ( $\alpha-, \beta-, \gamma$-, and $\delta$-tocopherol). Similar results have previously been observed in Perilla seeds (Park et al., 2004; Shin and Kim, 1994), however, in these cases, only one variety was used, and the name was not clearly identified. FL showed a higher level of seed vitamin E $\left(170.1 \mathrm{mg} \cdot \mathrm{kg}^{-1}\right)$ than $\mathrm{FW}, \mathrm{CW}$, or the two var. frutescens cultivars developed for seed (FCS) and leaf (FCL) purposes by the National Institute of Crop Science of the Rural Development Administration of Korea. Among accessions of the same type, highest total vitamin $\mathrm{E}$ content in seed was observed in accessions PO7-128 (204.9 $\left.\mathrm{mg} \cdot \mathrm{kg}^{-1}\right)$, PO7-59 (203.3 mg $\left.\mathrm{kg}^{-1}\right)$, PO7-24 (161.0 $\left.\mathrm{mg} \cdot \mathrm{kg}^{-1}\right)$ in FW, FL, and CW types, respectively. The average seed vitamin E content in Perilla crops $\left(152.1 \mathrm{mg} \cdot \mathrm{kg}^{-1}\right)$ was higher than that in various other seed oil crops, such as linseed $\left(83.0 \mathrm{mg} \cdot \mathrm{kg}^{-1}\right)$, mustard $(69.0$ $\left.\mathrm{mg} \cdot \mathrm{kg}^{-1}\right)$, and sesame $\left(100.0 \mathrm{mg} \cdot \mathrm{kg}^{-1}\right.$ ) (Ryan et al., 2007). Similarly, Bhandari et al. (2011) reported $132.5 \mathrm{mg} \cdot \mathrm{kg}^{-1}$ total vitamin E content in seeds of 12 var. crispa landraces collected in Korea and Japan. In contrast to the varying $\gamma$-tocopherol

Table 2. Descriptive statistics of vitamin E isomer contents $\left(\mathrm{mg} \cdot \mathrm{kg}^{-1}\right)$ in seeds and leaves of Perilla frutescens.

\begin{tabular}{|c|c|c|c|c|c|c|c|c|c|c|}
\hline \multirow{2}{*}{ Crop Type } & \multirow{2}{*}{$\begin{array}{l}\text { Descrip- } \\
\text { tives }\end{array}$} & \multicolumn{5}{|c|}{ Seeds } & \multicolumn{4}{|c|}{ Leaves } \\
\hline & & $\alpha-T^{z}$ & $\beta-T$ & $\gamma-T$ & $\delta-T$ & Total $-\mathrm{T}$ & $\alpha-T$ & $\beta-T$ & $\gamma-T$ & Total-T \\
\hline \multirow{5}{*}{$\begin{array}{l}\text { var. } \\
\text { frutescens } \\
\text { weedy type } \\
\text { (FW) }\end{array}$} & Minimum & 2.7 & 1.3 & 112.1 & 2.4 & 126.5 & 62.3 & 0.9 & 0.6 & 63.8 \\
\hline & Maximum & 12.1 & 10.7 & 187.5 & 6.1 & 204.9 & 364.2 & 2.4 & 4.1 & 368.1 \\
\hline & Mean & 6.8 & 5.7 & 135.4 & 4.6 & 150.1 & 244.6 & 1.6 & 1.4 & 247.7 \\
\hline & $\mathrm{SD}^{\mathrm{y}}$ & 3.1 & 2.5 & 18.7 & 1.0 & 18.8 & 98.9 & 0.6 & 1.0 & 100.0 \\
\hline & CV $(\%)^{x}$ & 45.6 & 43.9 & 13.8 & 21.7 & 12.5 & 40.4 & 37.5 & 71.4 & 40.4 \\
\hline \multirow{5}{*}{$\begin{array}{l}\text { var. } \\
\text { frutescens } \\
\text { landrace (FL) }\end{array}$} & Minimum & 8.5 & 1.4 & 124.5 & 2.5 & 140.5 & 172.0 & 0.9 & 0.8 & 173.6 \\
\hline & Maximum & 13.3 & 8.9 & 189.9 & 6.2 & 203.3 & 614.0 & 3.2 & 4.9 & 620.0 \\
\hline & Mean & 10.3 & 5.0 & 151.9 & 4.5 & 170.0 & 308.0 & 2.0 & 1.8 & 311.7 \\
\hline & SD & 1.4 & 3.1 & 21.7 & 1.1 & 21.0 & 113.3 & 0.5 & 0.9 & 114.2 \\
\hline & CV (\%) & 13.6 & 62.0 & 14.3 & 24.4 & 12.4 & 36.8 & 25.0 & 50.0 & 36.6 \\
\hline \multirow{5}{*}{$\begin{array}{l}\text { var. crispa } \\
\text { weedy type } \\
\text { (CW) }\end{array}$} & Minimum & 4.4 & 1.8 & 105.2 & 3.4 & 117.6 & 243.4 & 1.5 & 0.6 & 245.5 \\
\hline & Maximum & 6.9 & 10.1 & 137.9 & 6.7 & 161.0 & 318.6 & 2.1 & 1.8 & 322.5 \\
\hline & Mean & 6.0 & 4.1 & 120.9 & 4.7 & 135.7 & 274.9 & 1.7 & 1.4 & 278.1 \\
\hline & SD & 0.8 & 3.1 & 11.8 & 1.2 & 14.7 & 39.0 & 0.3 & 0.7 & 39.8 \\
\hline & CV (\%) & 13.3 & 75.6 & 9.8 & 25.5 & 10.8 & 14.2 & 17.6 & 50.0 & 14.3 \\
\hline \multirow[t]{2}{*}{ FCS } & Mean & 5.7 & 1.2 & 134.6 & 3.7 & 145.2 & 291.2 & 2.0 & 2.2 & 295.3 \\
\hline & SD & 0.2 & 0.2 & 5.5 & 0.3 & 6.2 & 92.1 & 0.4 & 0.3 & 92.8 \\
\hline \multirow[t]{2}{*}{$\mathrm{FCL}$} & Mean & 11.1 & 1.3 & 144.8 & 2.3 & 159.4 & 354.0 & 2.1 & 2.1 & 358.1 \\
\hline & SD & 0.1 & 0.1 & 12.1 & 1.7 & 13.9 & 112.2 & 0.3 & 0.8 & 111.7 \\
\hline Mean & & 8.0 & 3.5 & 137.5 & 4.0 & 152.1 & 294.5 & 1.9 & 1.8 & 298.2 \\
\hline
\end{tabular}

${ }^{\mathrm{z}} \mathrm{T}$ : Tocopherol.

${ }^{\mathrm{y}} \mathrm{SD}$ : Standard deviation.

${ }^{\mathrm{x}} \mathrm{CV}$ : Coefficient of variation. 
levels in seeds, leaves of all types of $P$. frutescens had the highest content of $\alpha$-tocopherol among three tocopherols ( $\alpha$-, $\beta$ - and $\gamma$-tocopherol) quantified. Compared to seeds, leaves of all crop types showed higher total vitamin E contents. The average leaf vitamin E content was $298.2 \mathrm{mg} \cdot \mathrm{kg}^{-1}$, which was higher than that in various vegetable crops, including broccoli $\left(17.7 \pm 3.4 \mathrm{mg} \cdot \mathrm{kg}^{-1}\right)$ and asparagus $\left(12.4 \mathrm{mg} \cdot \mathrm{kg}^{-1}\right)($ Chun et al., 2006). We observed the highest leaf vitamin E content in FCL (358.1 $\mathrm{mg} \cdot \mathrm{kg}^{-1}$ ) among the accessions of cultivated and weedy types of Perilla analyzed in this study, although this cultivar was not intentionally bred for high vitamin E content. Among accessions of the same type, accessions PO7-87 (368.1 $\left.\mathrm{mg} \cdot \mathrm{kg}^{-1}\right)$, PO7-59 (620 $\left.\mathrm{mg} \cdot \mathrm{kg}^{-1}\right)$ and PO7-156 (322.5 $\mathrm{mg} \cdot \mathrm{kg}^{-1}$ ) exhibited highest leaf vitamin $\mathrm{E}$ in $\mathrm{FW}, \mathrm{FL}$, and CW types, respectively.

\section{Squalene Content}

Squalene, a precursor of phytosterol biosynthesis, has an important role in lowering cholesterol, as well as chemopreventive effects, but is rarely studied in Perilla crops. In our study, we found a considerable seed squalene ranging from 16.8 to $85.1 \mathrm{mg} \cdot \mathrm{kg}^{-1}$ compared to that reported in other crops, such as mustard $\left(5.0 \pm 0.5 \mathrm{mg} \cdot \mathrm{kg}^{-1}\right)$, sesame $(6.0 \pm 0.4 \mathrm{mg} \cdot$ $\left.\mathrm{kg}^{-1}\right)$, and linseed $\left(10.0 \pm 0.4 \mathrm{mg} \cdot \mathrm{kg}^{-1}\right)($ Ryan et al., 2007) (Table 3). Highest seed squalene content in various Perilla types; FW, FL, and CW was $77.7 \mathrm{mg} \cdot \mathrm{kg}^{-1}$ (Acc. No.: PO7-20), $85.1 \mathrm{mg} \cdot \mathrm{kg}^{-1}$ (Acc. No.: PO7-7) and $161.0 \mathrm{mg} \cdot \mathrm{kg}^{-1}$ (Acc. No.: PO7-24), respectively. FL $\left(65.5 \mathrm{mg} \cdot \mathrm{kg}^{-1}\right)$ had the highest average squalene content in seeds, followed by FW $(46.7 \mathrm{mg}$ • $\left.\mathrm{kg}^{-1}\right)$, FCL (44.5 $\left.\mathrm{mg} \cdot \mathrm{kg}^{-1}\right), \mathrm{FCS}\left(29.6 \mathrm{mg} \cdot \mathrm{kg}^{-1}\right)$, and CW (28.4 $\left.\mathrm{mg} \cdot \mathrm{kg}^{-1}\right)$. Perilla leaves exhibited higher squalene content than the seeds, with $\mathrm{CW}$ exhibiting the highest average squalene content $\left(719.3 \mathrm{mg} \cdot \mathrm{kg}^{-1}\right)$ among all $P$. frutescens types. The accessions with highest leaf squalene content among FW, FL, and CW types were PO7-48 (769.7 $\left.\mathrm{mg} \cdot \mathrm{kg}^{-1}\right)$, PO7-135 (947.4 $\left.\mathrm{mg} \cdot \mathrm{kg}^{-1}\right)$, and PO7-156 (980.2 $\left.\mathrm{mg} \cdot \mathrm{kg}^{-1}\right)$,

Table 3. Descriptive statistics of squalene and phytosterols (campesterol, stigmasterol, and $\beta$-sitosterol) contents $\left(\mathrm{mg} \cdot \mathrm{kg}^{-1}\right)$ in seeds and leaves of Perilla frutescens.

\begin{tabular}{|c|c|c|c|c|c|c|c|c|c|c|c|}
\hline \multirow[b]{2}{*}{ Crop Type } & \multirow[b]{2}{*}{ Descriptives } & \multicolumn{5}{|c|}{ Seeds } & \multicolumn{5}{|c|}{ Leaves } \\
\hline & & Squalene & $\begin{array}{l}\text { Campe- } \\
\text { sterol }\end{array}$ & $\begin{array}{l}\text { Stigma- } \\
\text { sterol }\end{array}$ & $\beta$-sitosterol & $\begin{array}{c}\text { Total } \\
\text { phytosterol }\end{array}$ & Squalene & $\begin{array}{l}\text { Campe- } \\
\text { sterol }\end{array}$ & $\begin{array}{l}\text { Stigma- } \\
\text { sterol }\end{array}$ & $\beta$-sitosterol & $\begin{array}{c}\text { Total } \\
\text { phytosterol }\end{array}$ \\
\hline \multirow{5}{*}{$\begin{array}{l}\text { var. } \\
\text { frutescens } \\
\text { weedy type } \\
\text { (FW) }\end{array}$} & Minimum & 16.8 & 18.2 & 25.4 & 393.4 & 442.0 & 141.5 & 42.6 & 73.3 & 740.5 & 872.0 \\
\hline & Maximum & 77.7 & 48.8 & 50.4 & 593.6 & 652.0 & 769.7 & 68.0 & 135.9 & 950.6 & 1087.7 \\
\hline & Mean & 46.7 & 33.7 & 37.7 & 477.2 & 548.6 & 497.9 & 59.6 & 100.2 & 847.4 & 1007.2 \\
\hline & $S D^{z}$ & 18.3 & 12.1 & 7.0 & 60.0 & 60.1 & 214.8 & 8.3 & 23.3 & 65.2 & 64.3 \\
\hline & $\mathrm{CV}^{\mathrm{x}}(\%)$ & 39.2 & 35.9 & 18.6 & 12.6 & 11.0 & 43.1 & 13.9 & 23.3 & 7.7 & 6.4 \\
\hline \multirow{5}{*}{$\begin{array}{l}\text { var. } \\
\text { frutescens } \\
\text { landrace } \\
\text { (FL) }\end{array}$} & Minimum & 50.8 & 21.4 & 22.3 & 461.0 & 507.4 & 227.7 & 45.7 & 73.8 & 598.3 & 721.6 \\
\hline & Maximum & 85.1 & 48.5 & 47.7 & 607.8 & 671.0 & 947.4 & 81.4 & 113.8 & 1068.8 & 1243.2 \\
\hline & Mean & 65.5 & 33.3 & 32.1 & 523.5 & 588.9 & 591.2 & 65.0 & 94.5 & 861.1 & 1020.7 \\
\hline & SD & 10.1 & 11.1 & 8.0 & 42.2 & 46.7 & 239.4 & 9.1 & 12.1 & 108.3 & 119.8 \\
\hline & CV (\%) & 15.4 & 33.3 & 24.9 & 8.1 & 7.9 & 40.5 & 14.0 & 12.8 & 12.6 & 11.7 \\
\hline \multirow{5}{*}{$\begin{array}{l}\text { var. crispa } \\
\text { weedy type } \\
\text { (CW) }\end{array}$} & Minimum & 25.3 & 16.6 & 29.7 & 355.0 & 401.2 & 496.1 & 64.1 & 90.7 & 902.5 & 1057.3 \\
\hline & Maximum & 35.7 & 48.5 & 54.3 & 466.7 & 557.4 & 980.2 & 74.9 & 159.9 & 970.3 & 1205.1 \\
\hline & Mean & 28.4 & 28.0 & 38.8 & 412.3 & 478.9 & 719.3 & 70.8 & 124.4 & 931.7 & 1126.9 \\
\hline & SD & 3.2 & 13.6 & 9.3 & 32.9 & 45.8 & 244.2 & 5.9 & 34.6 & 34.9 & 74.3 \\
\hline & CV (\%) & 11.3 & 48.6 & 24.0 & 8.0 & 9.6 & 33.9 & 8.3 & 27.8 & 3.7 & 6.6 \\
\hline \multirow[t]{2}{*}{ FCS } & Mean & 29.6 & 16.6 & 23.5 & 440.2 & 480.2 & 100.8 & 34.4 & 54.1 & 614.7 & 703.2 \\
\hline & SD & 4.9 & 1.7 & 6.7 & 90.7 & 95.7 & 32.9 & 7.2 & 1.3 & 4.7 & 13.2 \\
\hline \multirow[t]{2}{*}{$\mathrm{FCL}$} & Mean & 44.5 & 19.5 & 28.5 & 459.4 & 507.3 & 176.9 & 37.2 & 75.7 & 584.6 & 697.6 \\
\hline & SD & 5.4 & 1.8 & 5.2 & 19.9 & 12.9 & 39.0 & 2.1 & 0.8 & 16.3 & 14.9 \\
\hline Mean & & 42.9 & 26.2 & 32.1 & 462.5 & 520.8 & 417.2 & 53.4 & 89.8 & 767.9 & 911.1 \\
\hline
\end{tabular}

${ }^{\mathrm{z}} \mathrm{SD}:$ Standard deviation.

${ }^{\mathrm{x}} \mathrm{CV}$ : Coefficient of variation. 
respectively. The presence of a high quantity of squalene enriches the medicinal value of Perilla crops, as it possesses antitumor, anti-proliferative, and serum-cholesterol-lowering effects (Khor and Chieng, 1997). Thus, both Perilla seeds and leaves could be good sources of squalene, thereby enriching its pharmacological value.

\section{Phytosterol Content}

Three major phytosterols, campesterol, stigmasterol, and $\beta$ -sitosterol, were analyzed in both the seeds and leaves of the different $P$. frutescens types. In both the leaves and seeds of all types, $\beta$-sitosterol was present in highest quantity, followed by campesterol and stigmasterol (Table 3 ), which was similar to previous studies on different plants (Normen et al., 1999; Ryan et al., 2007; Weihrauch and Gardner, 1978). The highest levels of campesterol, stigmasterol, and $\beta$-sitosterol in seeds were present in types $\mathrm{FW}\left(33.7 \mathrm{mg} \cdot \mathrm{kg}^{-1}\right), \mathrm{CW}\left(38.8 \mathrm{mg} \cdot \mathrm{kg}^{-1}\right)$, and FL $\left(523.5 \mathrm{mg} \cdot \mathrm{kg}^{-1}\right)$, respectively. Both cultivated and weedy types of var. frutescens accessions exhibited higher seed total phytosterol $\left(548.6 \mathrm{mg} \cdot \mathrm{kg}^{-1}\right.$ in $\mathrm{FL}$, and $588.9 \mathrm{mg} \cdot$ $\mathrm{kg}^{-1}$ in FW) compared to CW, FCS, and FCL. Similarly, highest seed total phytosterol was present in PO7-128 (652.0 $\left.\mathrm{mg} \cdot \mathrm{kg}^{-1}\right), \mathrm{PO} 7-39\left(671.0 \mathrm{mg} \cdot \mathrm{kg}^{-1}\right), \mathrm{PO} 7-24\left(557.4 \mathrm{mg} \cdot \mathrm{kg}^{-1}\right)$ accessions of FW, FL, and CW types, respectively.

In leaves, all accessions of cultivated and weedy types of Perilla crops showed higher total phytosterol, as did each of the corresponding phytosterols, than levels in seeds. CW exhibited the highest campesterol $\left(70.9 \mathrm{mg} \cdot \mathrm{kg}^{-1}\right)$, stigmasterol (124.4 $\left.\mathrm{mg} \cdot \mathrm{kg}^{-1}\right)$, and $\beta$-sitosterol $\left(931.6 \mathrm{mg} \cdot \mathrm{kg}^{-1}\right)$, as well as total phytosterol content $\left(1126.9 \mathrm{mg} \cdot \mathrm{kg}^{-1}\right)$ than other types. Perilla accessions: PO7-15 (1087.7 $\left.\mathrm{mg} \cdot \mathrm{kg}^{-1}\right)$, PO7-49 $\left(1243.2 \mathrm{mg} \cdot \mathrm{kg}^{-1}\right)$ and PO7-155 (1205.1 $\left.\mathrm{mg} \cdot \mathrm{kg}^{-1}\right)$ exhibited highest amount of total phytosterols among the accessions of FW, FL, and CW types, respectively. The presence of considerable amounts of phytosterols in both the leaves and seeds of two cultivated types of Perilla increases its medicinal importance, as these compounds have diverse physiological as well as pharmacological activities, such as cholesterol-lowering (Jones et al., 1997) and anti-tumor effects (Raicht et al., 1980).

\section{Correlations among Phytonutrients}

To understand the accumulation pattern of phytonutrients as well as to examine the possibility of breeding a phytonutrient-enriched variety of $P$. frutescens, the correlationships among lipophilic phytonutrients in seeds or in leaves were examined for each type of $P$. frutescens. In seeds, total vitamin $\mathrm{E}$ was strongly and positively correlated with squalene in weedy type of FW $\left(\mathrm{r}=0.723^{* *}\right)$ and $\mathrm{CW}(\mathrm{r}=$ $\left.0.871^{* *}\right)$, but was not correlated with that in the case of FL (Table 4). Likewise, vitamin E content also showed a positive correlationship with $\beta$-sitosterol in FW and FL. Among seed phytonutrients analyzed, $\beta$-sitosterol exhibited highest

Table 4. Correlation coefficients among lipophilic phytonutrient contents in Perilla frutescens seeds.

\begin{tabular}{|c|c|c|c|c|c|c|}
\hline Crop Type & Phytonutrients & Squalene & Campesterol & Stigmasterol & $\beta$-sitosterol & Total phytosterols \\
\hline \multirow{5}{*}{$\begin{array}{l}\text { var. frutescens } \\
\text { weedy type (FW) }\end{array}$} & Total vitamin $\mathrm{E}$ & $0.723^{* *}$ & -0.141 & -0.289 & $0.848^{* *}$ & $0.784^{* *}$ \\
\hline & Squalene & & 0.178 & -0.225 & $0.656^{\star *}$ & $0.665^{\star \star}$ \\
\hline & Campesterol & & & $0.570^{* *}$ & -0.006 & 0.261 \\
\hline & Stigmasterol & & & & -0.318 & -0.087 \\
\hline & $\beta$-sitosterol & & & & & $0.960^{* *}$ \\
\hline \multirow{5}{*}{$\begin{array}{l}\text { var. frutescens } \\
\text { landrace (FL) }\end{array}$} & Total vitamin $\mathrm{E}$ & 0.439 & -0.035 & 0.003 & $0.848^{* *}$ & $0.758^{\star *}$ \\
\hline & Squalene & & 0.259 & 0.185 & $0.473^{*}$ & $0.521^{*}$ \\
\hline & Campesterol & & & $0.855^{\star *}$ & -0.007 & 0.378 \\
\hline & Stigmasterol & & & & 0.096 & $0.461^{*}$ \\
\hline & $\beta$-sitosterol & & & & & $0.919^{\star *}$ \\
\hline \multirow{5}{*}{$\begin{array}{l}\text { var. crispa weedy } \\
\text { type (CW) }\end{array}$} & Total vitamin $\mathrm{E}$ & $0.871^{* *}$ & 0.511 & 0.583 & 0.610 & $0.708^{*}$ \\
\hline & Squalene & & 0.590 & 0.505 & 0.594 & $0.704^{*}$ \\
\hline & Campesterol & & & $0.883^{* *}$ & 0.406 & $0.767^{\star}$ \\
\hline & Stigmasterol & & & & 0.260 & 0.651 \\
\hline & $\beta$-sitosterol & & & & & $0.891^{* *}$ \\
\hline
\end{tabular}

\footnotetext{
${ }^{*},{ }^{* *}$ Correlation is significant at the $P=0.05$ and $P=0.01$ levels, respectively.
} 
Table 5. Correlation coefficients among lipophilic phytonutrient contents in Perilla frutescens leaves.

\begin{tabular}{|c|c|c|c|c|c|c|}
\hline Crop type & Phytonutrients & Squalene & Campesterol & Stigmasterol & $\beta$-sitosterol & Total phytosterols \\
\hline \multirow{5}{*}{$\begin{array}{l}\text { var. frutescens } \\
\text { weedy type (FW) }\end{array}$} & Total vitamin $E$ & $0.748^{*}$ & 0.503 & 0.358 & -0.241 & -0.050 \\
\hline & Squalene & & $0.731^{*}$ & 0.441 & -0.291 & -0.042 \\
\hline & Campesterol & & & 0.576 & -0.330 & 0.003 \\
\hline & Stigmasterol & & & & -0.199 & 0.235 \\
\hline & $\beta$-sitosterol & & & & & $0.901^{* *}$ \\
\hline \multirow{5}{*}{$\begin{array}{l}\text { var. frutescens } \\
\text { landrace (FL) }\end{array}$} & Total vitamin $\mathrm{E}$ & 0.300 & $0.472^{*}$ & $0.484^{*}$ & 0.312 & 0.366 \\
\hline & Squalene & & 0.299 & 0.069 & 0.448 & 0.435 \\
\hline & Campesterol & & & 0.331 & $0.879^{* *}$ & $0.903^{\star *}$ \\
\hline & Stigmasterol & & & & 0.234 & 0.337 \\
\hline & $\beta$-sitosterol & & & & & $0.994^{* *}$ \\
\hline
\end{tabular}

${ }^{*},{ }^{* *}$ Correlation is significant at the $P=0.05$ and $P=0.01$ levels, respectively.

positive correlationship with total phytosterol content in all types of Perilla mainly due to its high compositional ratio among phytosterols. However, squalene, a precursor of phytosterols, showed positive relationship only with $\beta$ -sitosterol in FW and FL, but not in CW. Compared to seeds, phytonutrients in leaves exhibited relatively low correlations (Table 5) with $\beta$-sitosterol, which although showed positive correlationship with total phytosterol content in both FW (r= $\left.0.901^{*}\right)$ and $\mathrm{FL}\left(\mathrm{r}=0.994^{*}\right)$.

In summary, this study demonstrated that both seeds and leaves of Perilla may be good sources of vitamin E, squalene, and phytosterols. Among the four vitamin $\mathrm{E}$ isomers present in seeds, $\gamma$-tocopherol was found in the highest quantity in all of the Perilla types tested. Likewise, leaves exhibited higher total vitamin $\mathrm{E}$ content than seeds in all cases. Similarly, $\beta$ -sitosterol was more abundant than other forms of phytosterols in both seeds and leaves, and as in vitamin E, total phytosterol content was higher in leaves than in seeds. Comparatively, seeds of Perilla crops exhibited higher correlations among phytonutrients than leaves. This is the first study to provide the lipophilic nutritional value of various types of $P$. frutescens and to suggest a possible enhancement in phytonutrient values by using both leaves and seeds.

\section{Literature Cited}

Awad, A.B. and C.S. Fink. 2000. Phytosterols as anticancer dietary components: evidence and mechanism of action. J. Nutr. 130:2127-2130

Bhandari, S.R., J.K. Lee, and Y.S. Lee. 2011. Phytonutrient profile of purple perilla (Perilla frutescens var. crispa) seeds. Korean J. Crop Sci. 56:199-204.

Bhandari, S.R., S. Basnet, K.H. Chung, K.H. Ryu, and Y.S. Lee. 2012. Comparisons of nutritional and phytochemical property of genetically modified CMV-resistant red pepper and its parental cultivar. Hort. Environ. Biotechnol. 53:151-157.

Bouic, P.J. 2001. The role of phytosterols and phytosterolins in immune modulation: A review of the past 10 years. Curr. Opin. Clin. Nutr. Metab. Care 4:471-475.

Burton, G.W. and M.G. Traber. 1990. Vitamin E: Antioxidant activity, biokinetics, and bioavailability. Annu. Rev. Nutr. 10:357-382.

Burton, G.W. 1994. Vitamin E: Molecular and biological function. Proc. Nutr. Soc. 53:251-262.

Choi, Y.J. 1984. Deulkkae (Perilla frutescens var. frutescens): Story of folk custom in Korea. New Hort. 26:52-53.

Chun, J., J. Lee, L. Ye, J. Exler, and R.R. Eitenmiller. 2006. Tocopherol and tocotrienol contents of raw and processed fruits and vegetables in the United States diet. J. Food Comp. Anal. 19:196-204.

Khor, H.T. and D.Y. Chieng. 1997. Effect of squalene, tocotrienols and a-tocopherol supplementations in the diet on serum and liver lipids in hamsters. Nutr. Res. 17:475-483.

Kruk, J., H. Hollander-Czytko, W. Oettmeier, and A. Trebst. 2005. Tocopherol as singlet oxygen scavenger in photosystem II. J. Plant Physiol. 162:749-757.

Jones, P.J., D.E. Macdougall, F. Ntanios, and C.A. Vanstone. 1997. Dietary phytosterols as cholesterol-lowering agents in humans. Can. J. Physiol. Pharmacol. 75:217-227.

Lee, J.K. and O. Ohnishi. 2001. Geographical differentiation of morphological characters among Perilla crops and their weedy types in East Asia. Breed Sci. 51:247-255.

Lee, J.K. and O. Ohnishi. 2003. Genetic relationships among cultivated types of Perilla frutescens and their weedy types in East Asia revealed by AFLP markers. Genet. Resour. Crop Evol. 50:65-74

Lee, J.K., M. Nitta, N.S. Kim, C.H., Park, K.M. Yoon, Y.B. Shin, and O. Ohnishi. 2002. Genetic diversity of Perilla and related weedy 
types in Korea determined by AFLP analyses. Crop Sci. 42:2161-2166.

Makino, T. 1961. Makino's new illustrated flora of Japan. Hokuryukan Pub., Tokyo, Japan.

Makino, T., Y. Furuta, H. Wakushima, H. Fujii, K. Saito, and Y. Kano. 2003. Anti-allergic effect of Perilla frutescens and its active constituents. Phytother. Res. 17:240-243.

Marangoni, F. and A. Poli. 2010. Phytosterol and cardiovascular health. Pharmacol. Res. 61:193-199.

Moghadasian, M.H., B.M. McManus, D.V. Godin, R. Rodrigues, and J.J. Frohlich. 1999. Proatherogenic and antiantherogenic effects of probucol and phytosterols in apolipoprotein E-deficient mice: Possible mechanisms of action. Circulation 99:1733-1739.

Moreda, W., M.C. Perez-Camino, and A. Cert. 2001. Gas and liquid chromatography of hydrocarbons in edible vegetable oils. J. Chromatogr. A 936:159-171.

Munne-Bosch, S. and L. Alegre. 2002. The function of tocopherols and tocotrienols in plants. Crit. Rev. Plant Sci. 21:31-57.

Nitta, M. and O. Ohnishi. 1999. Genetic relationships among two Perilla crops, shiso and egoma, and the weedy type revealed by RAPD markers. Genes. Genet. Syst. 74:43-48.

Nitta, M. 2001. Origin of Perilla crops and their weedy type. Ph.D. dissertation, Kyoto University, Kyoto, Japan.

Nitta, M., J.K. Lee, and O. Ohnishi. 2003. Asian Perilla crops and their weedy forms: Their cultivation, utilization and genetic relationships. Econ. Bot. 57:245-253.

Normen, L., M. Johnsson, H. Adersson, Y. Van Gameren, and P. Dutta. 1999. Plant sterols in vegetables and fruits commonly consumed in Sweden. Eur. J. Nutr. 38:84-89.
Park, K.Y., C.S. Kang, Y.S. Lee, Y.H. Lee, and Y.S. Lee. 2004. Tocotrienol and tocopherol content in various plant seeds. Korean J. Crop Sci. 49:207-210.

Raicht, R.F., B.I. Cohen, E.P. Fazzini, A.N. Sarwal, and M. Takahashi. 1980. Protective effect of phytosterols against chemically induced colon tumors in rats. Cancer Res. 40:403-405.

Rao, C.V., H.L. Newmark, and B.S. Reddy. 1998. Chemopreventive effect of squalene on colon cancer. Carcinogenesis 19:287-290.

Ryan, E., K. Galvin, T.P. O'Connor, and A.R. Maguire. 2007. Phytosterol, squalene, tocopherol content and fatty acid profile of selected seeds, grains, and legumes. Plant Foods Hum. Nutr. 62:85-91.

Shin, H.S. and S.W. Kim. 1994. Lipid composition of Perilla seed. J. Am. Oil Chem. Soc. 71:619-622.

Trebst, A., B. Depka, and H. Hollander-Czytko. 2002. A specific role for tocopherol and of chemical singlet oxygen quenchers in the maintenance of photosystem II structure and function in Chlamydomonas reinhardtii. FEBS Lett. 516:156-160.

Ueda, H., C. Yamazaki, and M. Yamazaki. 2002. Luteolin as an anti-inflammatory and anti-allergic constituent of Perilla frutescens. Biol. Pharm. Bull. 25:1197-1202.

van Rensburg, S.J., W.M. Daniels, J.M. van Zyl, and J.J. Taljaard. 2000. A comparative study of the effects of cholesterol, $\beta$ -sitosterol, glucoside, dehydroepiandrosterone sulphate and melatonin on in vitro lipid peroxidation. Metab. Brain Dis. 15:257-265.

Weihrauch, J.L. and J.M. Gardner. 1978. Sterol content of foods of plant origin. J. Am. Diet. Assoc. 73:39-44. 